\title{
A Civilisation without Toilets? Ibadan and Her Environment in the Post-colonial Era
}

\author{
Soji Oyeranmi ${ }^{1,2}$ \\ ${ }^{1}$ Department of History, University of South Africa (UNISA), South Africa \\ ${ }^{2}$ Department of History and Diplomatic Studies, Olabisi Onabanjo University, Nigeria
}

Copyright $\bigcirc 2018$ by authors, all rights reserved. Authors agree that this article remains permanently open access under the terms of the Creative Commons Attribution License 4.0 International License

\begin{abstract}
It is incontestable that Ibadan presents a despicable environmental picture. In fact, Francis, Egbhokare's revised Standard version of Professor J.P Clark's Ibadan: 'Ibadan/oozing blob of rot and mold squashed and splattered among human wastes/ like Bodija market in the rain' vividly captured the filthy nature of $21^{\text {st }}$ century Ibadan. Indeed, like most of the Nigeria urban areas, there is little evidence of any realistic physical planning. Visits to major streets and residential areas especially the core city centers show a prevalence of uncontrolled heap of refuse in open spaces and all pervasive repulsive odour of open sewers. There is also infrastructural decay: deplorable roads, pitifully inadequate water supply, erratic electricity supply and acute shelter shortage. The picture is generally that of urban disarray. At the heart of problem is the ubiquitousness of non-industrial and industrial pollutants. Individual and corporate bodies are reckless in waste storage and disposal often resulting in environmental hazards inimical to animal and human health. Despite the above environmental challenges, little attention is currently given to the problems. Indeed, many have concluded that filthiness in Ibadan is cultural in origin as the people are dirty by nature. This is why this paper is set to: establish the interdependence of nature and culture on one hand and sanitation and the environment on the other; investigate the root of sanitation crisis in Ibadan; identify stakeholders and their roles in environmental management in Ibadan; examine the efficacy of the governmental strategies in environmental management in Ibadan; assess peoples' attitude and perception to personal hygiene, environmental management and the implications of on their health; suggest some ways out of the crisis.
\end{abstract}

Keywords Ibadan, Nigeria, Urban Areas, Environmental Hazards, Sanitation, Nature, Culture

\section{Introduction}

This paper contends that the impact of British colonial rule on the growth and expansion of Ibadan (like most of Nigerian cities) was a near-absolute paradox. On one hand, the colonial urban environmental policies engendered unprecedented growth in Ibadan. On the other hand, it initiated enduring environmental crises which negated the much touted positive contributions of colonial urbanism. Sadly, these identified environmental crises endured from colonial times to post-colonial era in Ibadan. Expectedly, as the city continues to experience series of development activities since independence in 1960, environmental hazards kept arising from a wide array of sources which included the issues discussed earlier in this study. These problems have more direct and immediate negative impact on urban planning, waste management and sanitation with horrendous implications for human health and safety especially for the poor. The urban poor basically housed in slums or squatter settlements often have to contend with appalling overcrowding, bad sanitation and contaminated water. The sites are often illegal and dangerous. Forcible evictions, floods and road slides and pollution are constant threats.

However, it is important to note that factors responsible for the dire challenges of environmental management in Ibadan during the post-colonial era are in two-folds. First, efforts made to remedy the existing environmental problems especially urban planning, waste management and sanitation in Ibadan have been largely inadequate and so ineffective. Second, for more than four decades after independence from colonial rule, the city administrators did not recognize the need to focus on sustainable development, which is the only way to sustain the process of development for the future generations. It was therefore not surprising that they failed to entrench effective environmental management strategies into the developmental agenda of Oyo State as a whole and Ibadan particularly. What was required therefore during the early decades of the post-colonial era was a balance between development aimed at upgrading the quality of life and the conservation of the city's environmental quality. However, the failure to successfully tackle these environmental 
challenges over the years is responsible for the worsening environmental situations in Ibadan. This has resulted in some of the most severe negative implications for the development of the city.

In view of the above, with a primary focus on Ibadan, this study is to examine: City, Environment and Sustainable Development; the Stakeholders and the Environment vis-à-vis the various urban environmental problems that are confronting the city in post-colonial period; and suggest some new strategies toward tackling the issues.

\section{City, Environment and Sustainable Development}

According to Mahadevia (1), the drive to ensure that the sporadic urbanization which is a revelation of rapidity of human civilization is sustainable has led to the creation of the concept of "Sustainable Cities." As usual the Sustainable Cities Project (SCP) has impacted positively in cities in developed parts of the World while vast majority of cities in the Third World still largely remain huge squalors and mostly unsustainable. Thus, most First World Cities have become ecological havens through: taking in to account economic development and environmental costs of urbanization; self-reliance in terms of resource production and waste absorption; cities become compact and energy sufficient; and the needs and rights of all are well balanced. Mahadevia (2). Mahadevia (3) argues further that cities in the underdeveloped parts of the World could only be sustainable if: there is environmental sustainability; social equity; economic growth and redistribution and; the empowerment of the disempowered. This clearly shows the close link between environment and development.

In the opinion of Rodney (4), across ages, man has always exploited his natural environment in order to make a living. This does not only reflect the unbreakable nexus between environmental sustainability and human development but also authenticates the fact that existence of Flora and Fauna has been central to human existence on earth. Indeed, the totality of man depends on the environment; he walks on land, works on it, builds on it; might die and be buried on it. While Commenting on the link between environment and human development, Mabogunje observed that apart from the fact that all development takes place within an environment, it often gives direction to development in cities. According to him, cities have special role to play in this linkage as they are primary to development. To drive home his points, Mabogunje (5) further argued that:

Cities are engines of growth and development. Because production mostly takes place in cities, we usually have chains of demand and supply. On the supply side, you have people who are making or producing things such as agric implements or trading.
On the demand side, the workers will need food, so, their presence encourages rural areas to grow. Sometimes, people have funny idea that the only way to encourage Africa's development is to concentrate solely on agriculture but agriculture cannot grow without markets. Cities naturally provide these markets. And as the cities continue to provide these markets, the more they enhance the growth and productivity of the rural areas. This may be achieved by bringing machinery to the rural areas. This enhanced productivity will in turn be reducing the number rural dwellers; as many of them would have to move to the urban centres, which are presenting more economic opportunities for them. And as cities continue to grow, the numbers of people in the rural areas continue to reduce. This is why we have countries like the USA with just 3\% rural population.

In demonstrating the real link between environment and development in cities, the erudite urban geographer observed further that:

The environment provides the raw materials which urban centres usually process for an increased productivity. Man has always depended on his environment for survival. From the earliest times to the 1700s (an era characterized by low productivity), the relationship between man and environment was governed by mutual respect. But with industrial revolution which brought about mass production and consumption (in cities) with a very high impact on the environment, things started changing for the worse. Due to technological driven and energy sapping industrialisation, we have depleted ozone layer globally which has led to climate change. With this, environment seemed to have gotten to full circle, thus turning against our excesses. There are also other lesser problems such as poor urban planning, sanitation and waste management. Cities do import a lot, thereby generating enormous waste through consumption. Mabogunje (6).

The close relationship between Development and environment in Cities was also recognised by the UN (7), at a conference on human settlements in Vancouver June 1976. The forum concluded that problems of uncontrolled population growth, rural stagnation, migration, the inability of urban centers to cope with the rate of population increase and environmental deterioration demand corrective action at both the national and international levels. This is why Borofice (8) rightly linked the current global environment crises to the development crisis, both of which are the result of unsustainable system of production and consumption in the North, inappropriate development models in the south and a fundamentally inequitable world order. As a corollary, this study also recognizes the fact that the ecological crisis in Ibadan as in most sub Saharan African cities is a reflection of overall 
underdevelopment of the city. As observed by Renner (9), it is unfair to blame series of security and developmental challenges in African cities on the persistent primordial hatred among the people because the underlying cause is more likely to involve environmental degradation, which in turn led to depletion of natural endowment. Consequently, cities rather than providing the basis for sustained economic growth therefore have become serious impediments to development in sub Saharan Africa and disputes are often sharpened or even triggered by glaring social and economic inequalities. Regrettably, no place in sub Saharan Africa seemed to be immune against this tremendous tragedy, though, the impact varies from place to place. Nigeria as one of the few countries in sub Saharan Africa, which had many large pre-industrial cities in the opinion of Fourchard (10), could not possibly be an exception to the African urban environmental decay. While the world is full of both urban environmental "successes" and "failures", most African cities are examples of urban decadence; Ibadan is particularly notorious in this regard.

At the heart of the crises is the fact while most cities in the developed World have taken concrete actions to entrench sustainable development plans; most cities in the underdeveloped countries, especially in sub-Saharan Africa, are yet to have effective programs or sustainable national action plans to ensure provision of the basic necessities of life and maintaining decent and healthy environment. For this reason, most cities in post- colonial sub Saharan African that ought to be "epic centers of development" are bogged down with severe environmental problems. Ibadan is not an exception! For this reason, post-colonial Ibadan like most urban centers in sub-Saharan Africa has become a "sick city" overwhelmed by air pollution, noise, traffic, waste, racial tension, slum conditions, maladministration and many other urban malaises. Werlin (11). Onibokun (12) equally concluded that "today, the hearts of many cities in Africa are like islands of poverty in the seas of relative affluence." Other challenges include: the deterioration of basic services, housing and environment, mass unemployment and underemployment, the virtual absence of State welfare and many more. All of this culminated in what Lindell (13) called "urban crisis." Although the impact of environmental problems in Africa's urban centres vary from place to place, no place in sub Saharan Africa seem to be immune against the tragedy. As one of the many cities in sub Saharan Africa, which inherited grievous damages from colonial urbanism, Ibadan cannot possibly be an exception to the African urban environmental decay.

Given its size, as one of the largest cities in West Africa and Nigeria, the study of environmental management and development of Ibadan, presents a very significant window of opportunity to grasp the situations in most of other Nigerian cities( especially at the postcolonial period). The choice of Ibadan is premised on the fact by Labinjoh (14), that city serves as microscopic images of their societies.
Thus, Ibadan as a micro society within a larger entity is a reflection of the metropolis called Nigeria and could also be said to visibly depict the convoluted developmental processes of the country. The general signs include but not limited to: incessant and chaotic political situation, mass illiteracy, endemic poverty, admixture of traditionalism and modernism, unregulated industrialisation, inadequate town planning and lack of adequate urban environment management strategies. Postcolonial Ibadan no doubt has been a great cosmopolitan city in Nigeria and the history of her environmental challenges actually reflect the history of Nigeria's ecological conundrum. Onibokun: 1987, Abumere: 1987, NISER: 1997, Labinjoh, 1999, and Fourchard: 2003(15).

Ibadan was described by Llyod (16) as a "city- village." This description truly reflects the frenetic mixture of traditionalism and modernism in most African "modern cities". Post-colonial Ibadan as this study shows continues to draw more people to her expansive land and over the years has developed a paradoxical character. Like other pre-industrial societies, Ibadan, even after independence presents a sprawling agglomeration of buildings, spread out in numerous directions without any coherent order. At the same time, as Adelugba (17) demonstrates the frantic pressure and restless energy associated with modern metropolis. Unfortunately, the environmental disorderliness, which has been ravaging this huge urban space has become dreadful. Yet, both government and the people are seemingly growing more apathetic about environmental issues. It is therefore not surprising that Ibadan appears today as "a crippled city" in terms of environmental management and development.

This study fully recognizes the fact that a lush/healthy environment is not a luxury and that environmental sustainability is at the heart of a meaningful development through effective environmental techniques, thus, reinforcing the unbreakable link between environment and development. Unfortunately, failure of environmental management strategies has been a recurring decimal in the history of Ibadan. Things have become worse and almost unbearable at the post-colonial times. Consequently, the city is experiencing constant environmental hazards such as: poor sanitation, inefficient waste management, outbreak of epidemics, incessant flooding, unregulated urban planning and many more. Some experts and non-experts alike are blaming most of the post-colonial environmental crises in Ibadan on the negative handling of the environment by most of the stakeholders.

\section{The Stakeholders and the Environment in Post-colonial Ibadan}

Thus far, it has been established that cities are the world's greatest assets for pursuing sustainable development. This is because cities in the opinion of 
UN-habitat (18) are the areas with the highest possibility and ability to create economic growth and have also continued to play an increasingly significant role in regional and spatial development policy. Sadly, most cities in sub-Saharan Africa in post-colonial era are not agents of sustainable development due largely to horrendous environmental history inherited from previous generations. While it is true that every generation lives and works in an inherited environment shaped, in some cases, by very distant predecessors; but this does not foreclose environmental rejuvenation by successive generations. With a primary focus on Ibadan, this chapter intends to raise environmental consciousness of Nigerians in this direction. In order to harness Ibadan and other Nigerian cities as assets, all stakeholders must synergies and be committed to the ideals of sustainable development. The absence of this essential symbiotic relationship among the critical stakeholders in the management of environment is at the heart of ecological crisis in post-colonial Ibadan. Stakeholders in this case include: the government, the people and few companies in post-colonial Ibadan.

No doubt, cities as observed by Daly and Cobb (19), have become dynamic centers of economic growth and development: providing jobs, education, and markets and often producing more than twice their proportional share of GNP. According to the Commonwealth (20), if this growth can be sustained and if these cities can help to manage the wastes and pollution that threaten to engulf them, then, those same cities can provide one of the most important contributions to a sustainable world environment. Hence, efficient environmental management has become pivotal in ensuring that cities play that historic role as drivers of balanced and equitable development. As Stefan (21) has argued, not only can well managed environmentally sustainable - cities contribute to health, welfare and productive capacity of their own citizens, but they can also make a major contribution to environment sustainability and economic development on a global scale. This work denounces the hitherto widely circulated belief that urbanization and economic development are antithetical to environmental sustainability and calls for strengthening the capacity and capability of cities across post-colonial Africa (especially, Nigerian cities) to protect the environment at this age of surging urbanization particularly in the areas of urban planning, waste management and sanitation. This is in line with the thought of Foster (22) that:

Environmental quality in rapidly growing areas (cities) is really a matter of choice; management, not chance, is the determining factor in deciding whether urban growth will help or harm the environment. Cities can capitalize on the same trends and resources which lead to economic growth and use them to invest in environmental infrastructure which will make that growth sustainable. To manage the life of a city is ultimately to choose a future: to identify priority objectives and the risks that threaten them and then to mobilize resources effectively with which to meet those threats.

The issues of government, governance and Urban Environmental Management (UEM) have been closely linked to the discourse(s) of development and the role(s) of the state, the market and the private sector and the citizens. Jeppesen, Eskemose, Andersen and Madsen $(23,24)$. But as the custodian and epitome of peoples' hope and aspiration towards personal and national development, government at all levels must ensure sustainable development of cities. Historically, the state was seen as the key promoter of development and the main responsible party and a dominant perspective in international development assistance was a belief that the developing countries should establish government institutions, draft legislation and carry out enforcement similar to the North. However, with growing dissatisfaction due to limited improvements in many countries, changing international political and economic regimes, new perspectives were aired by Kjaer (25) with the ambition of 'resolving state failures' or encounter 'bad governance'. The 'solutions' centred on 'good governance' that will allow markets to flourish and ultimately the private sector in tandem with state institutions now seen as the key promoters of development. Lately, UN-habitat $(26,27,28,29,31,32)$ advocated that public-private partnerships as a means of sharing the responsibility and/or seeking additional funds and/or involving new private and civil society- actors in the development efforts.

UN-HABITAT's Global Campaign on Urban Governance argues that there has never been a more important time than now, to focus on the quality of governance at the local level. The new social contract arising out of the emerging democratic dispensation, the strong reemergence of the civil society and the expansion of the public space, foster the need for taking responsibility and accounting for outcomes and impacts. In addition, the forces of globalization and the movement towards decentralization are putting cities and local governments under tremendous pressure to deliver an ever-expanding range of benefits. The realization of these expectations, however, is affected by several important realities related to urban governance.

Many observers such as Taiwo (33) have also noted that the quality of urban governance can make the difference between cities characterized by growth and prosperity and cities characterized by decline and social exclusion. What is most clear is that the quality of urban governance and management is critical to gaining the benefits and reducing the negative aspects of cities of any size. Afolayan $(34,35)$. The rapid growth of cities will put a premium on building institutions to address the problems of those cities.

In the present context, therefore, good urban 
governance describes a situation in which the mechanisms, processes and instruments for decision-making and action facilitate civic engagement and accountability. Regrettably, today, most cities in sub-Saharan Africa are experiencing differing levels of decline mainly due to the absence of good urban governance, Ibadan is no exception.

One of the most critical findings of this study is that there is no significant positive shift between the colonial and post-colonial eras in Ibadan due to extremely poor urban governance and grossly inadequate environmental management strategies. Indeed, there is a general consensus that the major problem of Ibadan has of always been planlessness which in the opinion of Taiwo $(36,37)$, was exemplified by the absence of master plan from the colonial period till the present. There have been a number urban policies and programs in Ibadan from the colonial to postcolonial times but these had been hampered greatly by halfhearted implementation and absence of master plan for Ibadan. All we have are skeletal plans for pockets of housing estates such as Bodija (1970), Jericho, Oluyole, and Ring Road. So, Ibadan has grown over the decades (still expanding) without a comprehensive plans or strategies to address the identified environmental challenges and develop the city. According to Afolayan (38):

Consequently, there has been growth without sustainable development; at best all we have is haphazard or convoluted development. To worsen the situation (unlike cities in the developed world) Ibadan is a contaminated city because there is no coherent city governance. For example, Ibadan metropolis has 5 LGAs and 6 at periphery which made extremely difficult if not impossible to have a comprehensive and a well-coordinated plans to development the city in a sustainable manner. Although there are existing environmental management policies but due to the absence of the needed synergy, coordinated implementation become impossible as these local governments always operate regularly in isolation with different orientation.

Closely related to the above according to Oyewole (39) is the absence of zoning arrangement in post-colonial Ibadan (in which land will be specifically allocated strictly for particular purposes and so demarcated). With zoning arrangement, areas meant for residential purpose would not be used for any other purposes; same thing goes for industrial area, markets areas, school areas, churches, mosques, shrines etc. Sadly, the near-zero presence of zoning arrangement is one of the most important reasons for the squalid nature of Ibadan (just as in many other Nigerian cities).

Daud $(40,41)$ posited that although, there were pockets of local plans, individual layouts but there is no general master plan, also claimed despite the fact the first School of Planning in Nigeria was founded in Ibadan; lack of development control tools and absence of development plans to guide the planning of the city had resulted into uncontrolled growth. Thus, the city was just growing in all directions without any coordination leading to haphazard development.

This was not due to lack of planning authorities but rather because of compromising attitude of the planners and lack of political will in the enforcement of environmental rules by successive governments at all levels. According to some of our informants (42) pervasive corruption, poor motivation, lack of commitment and undue familiarity between the environmental officers and Ibadan residents have also been fingered for this ineffective enforcement of planning laws and procedures. It was even alleged that at a point when Local Government Areas were in charge of planning at grassroots, a commissioner of Local Government Affairs gave instruction to the enforcement agencies that the moment that any building has gotten to lintel level and such building has violated any rule, such structure should not be demolished. So, Taiwo (42 observed that people took advantage of this by encroaching other peoples' lands; building on illegal plots of land and usually start work by Friday, by Monday the building would have gotten to lintel. The massive corruption and absence of proper enforcement of environmental laws have culminated in the city's infamous status as the dirtiest city in Africa. Oyewole and Popoola (43).

Loss of operational autonomy by Planning Authorities in Ibadan as argued by Daud $(44,45)$ also created enormous during and beyond our period of study. In the 1980s, we used to have independent Ibadan Metropolitan Planning Authority that was completely autonomous but things have changed drastically in this regard (since year 2000) as everything has been taken over the government. This has paved way for the undue interference from the government with serious negative implications for the growth and development of the city. This was further compounded by the problem of gross inadequate funding of environmental management particularly urban planning, waste management and sanitation in post-colonial Ibadan. This has led to: serious shortfall in the supply of modern/ critical facilities such as: incinerators, mobile refuse collectors; logistic crises in the areas of irregular payment of salary, extremely bad road networks, problems of office spaces and accommodation, transportation, little or non-existent running cost etc. However, under-staffing or shortage of man-power seems to the most vicious consequence of inadequate funding of environmental management by successive governments in post-colonial Ibadan. The fact was attested to by nearly all our informants as the problem have negatively affected (in the past) and still affecting the areas of physical planning, waste management and sanitation.

This definitely took a huge toll on other segments and 
compounding gravely other previously identified problems. For instances it was alleged that due to paucity of fund and contrary to the WHO recommendation of 1 environmental staff to 10,000 people, Oyo state within our period of study only employed less than 500 environmental officers to the population of over 6 million; less than 200 in Ibadan of close to 3 million people. This was despite to the fact that there were thousands of unemployed trained environment health personnel across the state and the city. In similar vein, with acute shortage staff (with the concomitant effect of over stretching and over stressing of few ones available) enforcement of environmental laws in the areas of waste management and urban planning became herculean (if not impossible) task. The implications of these are dire and enormous especially as the people are living in extremely poor sanitary conditions and badly managed urban environment which directly exposed them to serious health hazards, epidemics, floods etc. Although, government may take the lion share of blame for this crises (especially for near total failure to prioritize environmental sustainability in the bid to achieve economic development in Ibadan); the people (residents) could not also be exonerated from the enduring environmental conundrum that had been the lot of Ibadan since 1960. This stems principally from the lethargic and lackadaisical attitude of the people to environmental issues such as sanitation, waste management, urban planning.

As discussed above, constraints on sustainable development in cities across Sub-Saharan in Africa are legion. Some are general and others are sectoral or specific. Some are local while others are national or regional. It must also be admitted that, prior to the adoption of the current sustainable development paradigm, Sub-Saharan Africa lagged behind other regions in food security, standard of living, and various aspects of development. Consequently, the adoption of a new development paradigm that places more emphasis on combining economic development plans with environmental sustainability does not eliminate the existing constraints on sustainable development in the region. This study argues that failure of governments, organizations and institutions across the continent to put their citizens at centre of the developmental efforts is the most important factor for the backward trends in the attainment of sustainable development in our cities. To worsen the situation, most peoples in these countries lack the awareness of basic ideas about the concept of sustainable development. As a corollary, their participation and positive contributions towards establishing proper Urban Environment Management strategies become extremely low and near total counter-productive to sustainable development. The case of residents of post-colonial Ibadan is particularly notorious in this regard.

Indeed, some scholars like Ajayi (46) squarely place blame for filthy nature of post-colonial Ibadan on the doorstep of the people. According to him:

There are array of environmental problems confronting the post-colonial Ibadan which arose from the points that it is a city-village and that culturally the people are dirty-sometimes they eat on leaves which they usually throw around anyhow. Their fundamental environmental problem is poor sanitation as they mostly live in unhygienic environmental without proper disposal of waste especially in the core areas. The city do generates Volumes of waste more than what the government can manage. This is why you find refuse littering the major streets and sometimes heaps of wastes all over the place. These waste often eroded into drainages and rivers channels which usually resulted in erosion and floods during raining season. This does not exclude industrial wastes from industries around Ibadan. Even when incinerators and dump sites are provided, companies and people hardly make use of them; sometimes parents do send their kids who usually dump the refuse at the feet of the incinerator because they do not have the required strength to dump the refuse properly.

Ikwuyatum (47) equally shares this belief about the people of Ibadan when he submitted that:

With few access links, evacuation during disasters and even refuse disposal became difficult; people often use that excuse to throw garbage anywhere, anyhow. There is also cultural aspect to this. People around here believe in certain delicacies which require unique packaging in leaves etc. without much discipline as to dispose the waste properly. Indiscriminate dumping of refuse by market people into river channels and along the streets due to lack of monitoring and provision of needed infrastructure by the government.

Afolayan (48) even alleged that at some point, there seemed to be resistance from the traditional core areas of Ibadan against the attempts to modernize the areas. Although many of the occupants of this part of Ibadan resisted change from status quo partly due their cultural affiliation or familial links (family houses, grandfather's land etc.) as most of them were born there. But according to Adepoju (49) the main reason for 'being happy' living in the squalor in spite of the extremely limited facilities for human welfare was their economic and intellectual penury. To worsen the situation in the opinion of Fourchard (50), upper mobility among the multitude of slum dwellers right from colonial period to the post-colonial times in Ibadan was near impossibility due to extreme poverty-the number one enemy of sustainable development.

The investigation (51) conducted in selected core areas across the eleven Local Government Areas of Ibadan reveals that people mostly build without recourse to any plan; without regard to street layouts; encroach on roads thereby creating congestion and inaccessibility to those areas. Even in some places such as markets, walk-ways and roads are often blocked; thereby creating uneasy passage 
for both vehicular and human movements. Majority of the houses in those areas also have no toilets. When some of the residents of these areas were asked questions on how they defecate or even dispose of their wastes, a few of them (52) were sincere enough to open up that they usually dump their faces (and other wastes) in channels such as gutters, canals, rivers, streams, creeks, refuse sites, the streets, even on highways and roads. Even in the few houses where conveniences are available, they are pit latrines which are usually in state of dilapidation. These latrines are not well-constructed, they are roofless some of them are a sort of make-shift in structure either covered with rusted corrugated iron roofing sheets or uncovered at all; others are filled to the brim, almost spilling onto the bare ground, and one's face is greeted with maggots in an attempt to examine the state of such latrines. Sadly, some of the problems like (congestion, lack of access roads, indiscriminate dumping of refuse etc.) identified in the core city centres are now being replicated in the so-called new or modern areas in post-colonial Ibadan.

Uncontrolled population growth is also a problem (up till now, there is no accurate census figures for governments to be able to plan for the citizens). The population of the city is growing beyond the capacity of managers of the environment. This is being compounded by problems unregulated human habitation, careless consumption and reckless production activities of the few available small and big businesses in post- colonial Ibadan. Ikwuyatum (53) summed this up that:

One major problem of Ibadan is that of urban planning which reverberates around the tripartite concerns of human habitation, consumption and production. Due to absence of proper planning, the city is unable to cope with proceeds from these. Waste generated come largely from human consumption and production without effective disposal techniques (refuse always litter everywhere).

If the government lacks proper planning/environmental management philosophy and tenacity to enforce environmental laws; if the people are reckless in handling environmental issues: the few industries in post-colonial Ibadan also are not helping matters. The negative impact of industrial activities on the environment primarily stems from lack of master plan and the absence of zoning arrangement in post-colonial Ibadan (in which land will specifically allocated strictly for particular purposes and so demarcated). Personal visits and investigation $(54,55)$ reveal three main implications of this. In the first place, industrial and residential spaces are practically in one and the same place while factory production, especially of the large scale types is generally in buildings or premises separate from dwelling houses in the same vicinity. Examples of this situation could be seen in Sanyo Nig. Ltd. along Ibadan -Lagos Express Road, Odo-Oba and Askar Paints Nig. Ltd. at Eleiyele. The traditional craft such as blacksmith industry is also organized on cottage or compound basis. Second is the scattered nature of modern industries in Ibadan which is largely due to the location of the very few industrial estates namely: Oluyole, Old Lagos Road, Olubadan Industrial Estate, along New Ibadan/Ife express Road, Ajoda New Town and Eleiyele Light Industrial Estate. According to some of our informants (56) the Nigerian Breweries PLC has a modern brewery located next to Olubadan Estate along new Ife express way with some industries located round the place. The third pattern (which shows a slight improvement from the previous ones) is what now constitutes the fringe of Ibadan. This seems like a response to the changing patterns of urban development in the city as some industries are now located in those areas. For examples we have: Gas Cylinders Ltd. at Ejioku; Leyland Nigeria Limited at Iyana - Church; the Nigeria Wire and Cable Ltd. along Ibadan-Abeokuta Road Owode; the Standard Breweries at Alegongo Village; Eagle Flower Mills, Toll-Gate, The British-American Tobacco Company on Lagos-Ibadan Express Road new Toll-Gate Ibadan and many more.

With the above stated haphazard arrangement, it has become obvious why industries have been pivotal to environmental degradation of Ibadan despite of extremely low industrial activities. Although, the few industries also impacted negatively on other aspects environmental problems but they are most notorious in aspects waste generation (solid, gaseous and effluent) and pollution. With their "generous" pollutants, these emissions are mostly dispersed either up their 'chimneys' or down their sewage plants. The industrial sector has been contributing to the scourge of pollution, as admitted by some of our informants (57), who divided these wastes into solid wastes, liquid wastes or effluent wastes and gaseous ones. Though contribution of these industries to the economic growth of Ibadan may be relatively low; but the effects of their activities on the environment are very significant. Largely, industrial activities generate wastes as the industrial establishments struggle to make profit. Industrial pollution problems according to the World Bank (58) arise because of most manufacturing industries in Nigeria, only 18\% usually attempt basic recycling of wastes before disposal. The recent size and number of industries have in recent years increased due to incentives by the government to adopt Foreign Direct Investment (FDI) strategies to attract industries to the nation. Thus, the economic wealth they bring makes the government relax on industrialization laws, especially on emissions. Ibadan as one of the centers of industrial activities (like other cities in Nigeria) is facing a lot of environmental challenges due largely to unregulated industrial businesses.

While some scholars attempt to differentiate contributions of each stakeholder to the environmental degradation of post-colonial Ibadan (as we have seen above); others argued that these negative contributions are hardly separable as they deeply connected poverty, cultural 
perspective and attitude of the people; uncooperative attitude of small and big businesses; lack of capacity and absence of adequate planning philosophy on part of managers of waste. In the opinion of Ikwayatum (59):

Indeed, there are networks of interwoven problems confronting Ibadan from lack of planning to lack of discipline among the people and governments. All output from human consumption, output from industrial production are bundled into environmental problems confronting Ibadan. Sadly, nobody is thinking ahead for Ibadan even for the next 5 years (unlike Lagos with plans for the next 20 to 50). Health is wealth as they say but for any city to health and wealth, the environment must be healthy and sustainable. It is all about planning, economic activities, population growth, production and consumption which increasing waste generation. As the population is growing and their productive activities expanding, so will the consumption increasing resulting in the explosion in waste generation with negative implications for the city due to lack of planning, absence of capacity and inadequate waste disposal strategies. Pollution is a major outcome.

From all indications, all the stakeholders in Ibadan have made differing efforts in addressing the above mentioned environmental problems but the main issue here is that the attempts made to solve the problems were too minimal and negligible when compared to the ways those problems were created. This is why even in the post-colonial era critical environment-development issues in Ibadan largely remain: Inadequate provision and management of environment infrastructure, which consists of unrepaired water pipes, inability to generate sufficient funds, erratic power supply and poor management, all of which have prevented over half of Ibadan's residents from having access to potable water, with attendant health and economic problems; insufficient waste management services, that is a low solid waste collection rate which has resulted in illegal dumping, blocked drains, disruption of business in commercial areas, reduced road space and localised air pollution due to neighborhood incineration; flooding exacerbated by uncontrolled urbanization. Much of the city has no storm drains, sewers or gutters. This lack of drainage as observed by Busari and Olaleye (60) combined with shallow valley floors, increasing impermeabilisation and poor solid waste management has resulted in at least ten devastating floods from 1902 to 1980 and many more between 1980 and year 2000. These were worsened by settlement in flood plains and deforestation and hillsides. There are also problems of poor environmental health; inadequate water supply, water pollution, poor refuse disposal, crowded and sub-standard housing, contaminated food and disasters such as flooding have resulted in high health risks for Ibadan residents. As an extreme example a cholera epidemic given by Taiwo (61) claimed over, 10,000 in the early 1970s.

\section{The Way Forward: Toward Regeneration of Ibadan}

As reflected in the thought of Anna K. Tibaijuka, Africa ( like most undeveloped parts such as Asia and Latin America), high rates of urbanization have been accompanied by high levels of poverty and inequality, due mostly to near-absence of good governance and urban leadership in most of the cities. Tibaijuka (62) lamented further that:

\begin{abstract}
Urban inequality has a direct impact on all aspects of human development, including health, nutrition, gender equality and education. In cities where spatial and social divisions are deep, lack of social mobility tends to reduce people's participation in the formal sector of the economy and their integration in society. This exacerbates insecurity and social unrest which, in turn, divert public and private resources from social services and productive investments to expenditures for safety and security.
\end{abstract}

The above assertion is in no way suggesting that cities in the most developed parts of the world are totally immune against urban malaise. Indeed according to Sam Omatseye (63), "no city in the world, whether it is London, New York, Tokyo or Paris that did not pass through the foul rhythm of grime and crime before surging to a place of envy. However, the difference is that most of the cities in advanced parts of the world, if not all of them were fortunate enough to have leaders who are innovative, progressive and competent. These leaders were able to inspire them out of doom and transform them to become glorious human habitats and choice destinations for people around the world. For instance, the city of London today is celebrated for orderliness and enviable beauty, but it once groveled under Hitler's bombardments. However, it was that same tragedy that threw up the genius of the great Winston Churchill with his speeches of inspirational growl. Sadly, it is a gory story for post-colonial Ibadan (as in most other sub-Saharan African cities).

Ibadan contrary to early post-independence optimism remains a city-village characterized by near- absolute inequality. This can still be partly attributed to the heinous colonial legacy of 'duality' that led to existence of 'two cities' in one-the old core traditional centre and the new or emerging areas, which were (and still are) diametrically opposed to each other. With this contradiction, the city could not sustain the promises of an emerging 'global city' but rather became a city of massive physical distortions and vast disparities. To worsen the situation, most post-colonial leaders in Ibadan (with possible exception of Chief Obafemi Awolowo) did more damage to the urban 
environmental management and development of the city. Indeed, the beleaguered city fell into the hands of pillagers and bumblers who preferred the vanity of their sartorial splendour to the environment. The leaders loved themselves so much that there was not much love left for the city they pretend to govern. Consequently, rather than inspiring the city, 'they inspired filth. 'At a point in time within the scope of this chapter and beyond, Ibadan literally became overwhelmed with filth so much that, at every turn you are confronted with heaps of refuse intimidating traffic into paralysis. Things got so grave that the city in the opinion of Omatseye (64) was declared as one of the dirtiest cities in the world at the dawn of the new Millennium.

Despite these enormous difficulties; this study shared the optimism from the UN (65) that 'Our cities are up to the challenge to deliver a sustainable future.' More so, since these problems were created by man, it is also within the people's capacity to proffer possible panacea. As a study of 'cautious optimism,' it suggests that due to presence of great disequilibrium and disparities in the evolution and development of Ibadan, there is need for real evidence before 'we start dancing to a new rhythm of hope of urban rejuvenation.' Therefore, this study suggests a paradigm shift which must be anchored on attitudinal change in people and constructive changes in policies on part of the decision makers. The main suggestions are discussed below:

As it has been firmly established earlier, this study sees cities as drivers of sustainable development. The concept of sustainable development is a people-centred innovation that has initiated a positive drastic shift away from the existing traditional norms towards proffering enduring solutions to multi-faceted and dire difficulties confronting the global community (in the cities or rural areas) today. Apart from the fact that sustainable development is rooted in systems thinking; it also helps people around the world to understand themselves and the world. This is why, we strongly argue here that: while global community may not be able to address all the enormous problems that the planet earth is facing the same way the people have created them; our world can address the environmental crises more effectively if only people across the globe can heed advice of Mahadevia (66) by genuinely allowing core principles of sustainable development to always guide their conducts.

Furthermore, as a research that envisions cities as drivers of sustainable development, the current work is also guided by a new paradigm such as the urban ecosystem approach (which calls for concerted human efforts at tackling environmental crises). The urban ecosystem in opinions of Machlis and Nilon (67) is an approach that provides a framework for understanding the interactions between economic, social and ecological factors in the urban environment. This is because to solve nagging environmental challenges facing humanity successfully, it is imperative for policy makers at the local, national, regional and international levels to recognize the crucial role of cities in catalyzing shift towards sustainable development. The dawn of new Millennium in the year 2000 saw the concerted global effort at achieving this for cities around the world increased tremendously.

First and foremost, in order to achieve sustainable development and effectively tackle various environmental challenges confronting post-colonial Ibadan, the leaders must be ready "to provide leadership and encourage partnership in caring for the environment by inspiring, informing, and enabling communities and peoples to improve their quality of life without compromising that of future generations." (UNEP, 68). The people must also be prepared to make necessary sacrifice. To achieve this, the Sustainable Ibadan Project (SIP) must be revisited and creatively revised. The Sustainable Cities Programme (under which SIP was founded) essentially gave credence to the Urban Ecosystem Approach as it has a central commitment to the widest possible range of participation a wide range of "stakeholders" in urban environmental planning and management. This commitment according to UN-habitat (69) was not based on an abstract theory but on the practical reality that effective and sustainable environmental management requires the active and meaningful involvement of all those different groups, organizations and interests whose cooperation is necessary for successful action and implementation. Ultimately, as we have established earlier, success of environment management depends on proper involvement and synergy between the Public Sector and Private sector. At the Public sector level, SIP focused particularly on the local or metropolitan level and including all the relevant agencies, public tertiary institutions, departments, authorities, politicians, officials etc. On the private sector focus as prescribed by the SCP $(70,71)$ was on: the economic sectors (trade, business, industry etc.), both large-scale modern participants; those in the "informal" sector; the Community Sector; Non-Government Organizations (both at local and national levels); Community Based Organizations; Private Voluntary Organizations, special environmental interest groups and many more.

Obviously, creative environmental management is significant to cities everywhere. Not only can well managed environmentally cities become sustainable, contribute to health, welfare and productive capacity of their own citizens, but they can also make a major contribution to the world environment. No doubt, the SCP initiative with its responsiveness, flexibility, and a practical demonstration of Urban Ecosystem approach offered one best opportunities to achieve that. This critical initiative also sees the environment is a critical ingredient for the success or failure of urban development, and that participatory management is the most effective response to environmental concerns. Most importantly, the SCP (as an embodiment of Urban Ecosystems Approach and 
epitome of sustainable development) establishes all-inclusive management strategies. As a true paradigm shift away from the existing traditional norms, it seeks to synergies numerous stakeholders in urban development. It is based on the above stated premise that this study strongly advocates for an absolute revaluation of SIP documents (which are currently lying fallow at the SIP building in Ibadan) by both State and the 11 LGAs of Ibadan. If this could be done with utmost diligence and sincerity of purpose; its wide application and institutionalization in Ibadan will certainly inaugurates the much desired urban environmental revolution in Ibadan, which will have multiplier effects on other Nigerian cities.

Closely related to the need to revive SIP is the critical need to revolutionize urban governance in Ibadan. As it has been established earlier, one of the most constant features of environmental history of Ibadan was near zero presence of properly coordinated or good urban governance (which became more apparent during colonial and post-colonial eras). This has been hampering positive urbanism and making it impossible to achieve sustainable development in the city. At the level of city administration, concept of governance centres on the responsibilities in the management of cities, which is a very complex phenomenon. This involved a wide variety of stakeholders including local governments, States, national and regional governments; the private sector; non-governmental and community-based organizations (NGOs/CBOs), the media, professional associations and generality of the people. Achieving sustainability in our cities with such complexities certainly require technicalities of extreme proportions in propositions and implementation. Unfortunately, this had been largely lacking in Ibadan throughout her turbulent environmental history till today. As the quest for sustainable development in Ibadan continues, this study strongly advocates the inculcation and integration of the twin core principles of 'good urban governance -transparency and inclusiveness in to the city's urban environmental management strategies.

Apparently, poor urban governance inherited from the colonial era by post-colonial Ibadan is mainly responsible many maladies ravaging the city today. Lack of transparency and absence of free flow of information have led to non-inclusive administrative styles. This became manifest in the non-responsive allocation of resources leading to a disproportionate spending on the priorities of the few elite and the wealthy (especially large infrastructure projects), at the expense of the vast majority poor ( who usually lack access to basic benefits of urbanization such as employment, housing, water supply, proper sanitation etc). Worse still, the poor residents are forcefully pushed to the urban periphery and hazard prone areas through extremely exorbitant cost of land at the city centers and non-transparent land allocation practices by governments at all levels. In order to regenerate and turn Ibadan into 'an inclusive city' most of these anti-people's environmental policies must be reversed in favor of the people (particularly the poor).

Certainly, efforts at ensuring inclusiveness and regeneration of Ibadan without a master plan would be in complete nullity. This is why most experts and scholars (72) consulted agreed that a master plan is a must towards regenerating Ibadan. This will inaugurate centralized and well-coordinated city governance unlike the present arrangement of five and eleven Local Government Areas. Though the LGAs may subsist but they must be harmonized in terms of environmental management philosophy, policies and implementation. There should also be elaborate legislation to back environmental management techniques expected in the master plan for continuity and sustainable development. While everybody cannot benefit from infrastructural provisions at the same level, the expected Ibadan master plan must be an all-inclusive document containing environmental strategies that will embrace and take care of all relevant stakeholders like: the poor; the wealthy; politicians from diverse political affiliations and orientations; landlord associations; trade unions; market unions; NGOs; CBOs and relevant government agencies. The environmental challenges should also be comprehensively identified, studied and cleverly prioritized to ensure justice for all. For examples, the proposed master plan must be able to initiate drainage revolution and provide basic infrastructure such as feeder roads linking the communities to major roads. While the drainage revolution will eradicate incessant floods; feeder roads will equally greatly ease waste evacuation (especially in traditional core areas which have battled with congestion over the years). These apart from tackling issues of floods, waste management, sanitation and planning which are the 'deadliest' environmental crises confronting Ibadan, today; the actions will be serving the interest of the majority of the people.

Since poverty is one of the major factors debarring sustainable development in Ibadan; any effort at regenerating the city must include achieving economic development and prosperity for the people. This study rejects the common notion that urbanization and economic development are antithetical to environmental sustainability. Rather, it argues that drives for urban and economic development could complement environmental sustainability if the decisions are also committed to strengthening the role of cities in urban planning, waste management, sanitation and general protection of the environment. At their best, cities can be the principal drivers of economic, social development and even transformation. Business and industry can take advantage of shared access to labor, services, infrastructure, and information to lower costs and increase productivity. If these are in place, then urban consumers will continue to benefit from increased choice and the improved quality of goods and services. With such opportunities, cities (especially those in the developed part of the world) have 
become dynamic centers of economic growth and development: providing jobs, education, and markets and many more. Most of these advanced cities have been able to achieve sustainable growth because they are able to capitalize on the same trends and resources that led them to economic growth and invested heavily in environmental infrastructure. However, cities in most parts of the undeveloped world (especially in sub-Saharan Africa) are still very far away from sustainable development due to the prevalent urban poverty. Ibadan is no exception.

The poor in post-colonial Ibadan, were (still are) often the victims of urbanization processes in many aspects. Apart from the fact that most of them live in areas without access to basic amenities such as water, roads, toilets; they also work in most inhuman conditions without dignity of labor. Due to their level of poverty, thousands of them that engage in petty trading usually sell on the roads and sidewalks due to lack financial capacity to occupy legal lands or shops. Most of them are informal workers who operate on a day-to-day economic cycle. They work today in order to eat today. On the days they can't work - because they are ill, or because they are chased away from their workplace - they don't earn, and therefore don't eat. Expectedly, planners in Ibadan often had rough and hazardous entanglement with these unfortunate Nigerians for embarking on so called illegal activities for bare daily survival. But in order to have all-inclusive Ibadan that we are advocating for, authorities in the city must also take care of the socio-economic wellbeing of the poor (in their millions) as they plan and implement urban renewal programs.

This must start from the recognition of the sacred fact by those in authority that the poor in Ibadan also have 'the right to the City' as spelt out by Habitat III's Policy Unit 1. (73) This policy framework for sustainable cities as enunciated by Roever (74) is to ensure that cities prioritize people over profit. The Right to the City is a set of principles meant to guide decision-making processes in the best way possible to ensure good quality of life for all citizens irrespective of their socio-economic status by promoting and propagating: sustainability, equity and socio-economic justice. Such equitable relationship won't be so easy to accomplish but certainly not impossible. In the case of Ibadan and her millions of impoverished workers/residents, these principles can only be realized through organization, mobilization and meaningful engagement between city authorities and the people. The United Cities (75) admonished that the authorities must find ways to implement participatory consultation processes to make the voices of all the inhabitants heard. If Ibadan city authorities can achieve this, they will be in a better position to find ways to support existing livelihoods and to recognize the social production of the city. This in other words will mean that the processes are being carried out with the initiative and contribution of ordinary people.

Most importantly in order to ensure economic survival of the average citizens in Ibadan, the public and private authorities must evolve what Roever (76) calls "the people's economy"- with the target of lifting the poor out of their misery." This will allow them to grow their enterprises over time by providing stability and certainty in their work environment: whether through licenses, uniforms or identification cards that help them fend off those harassing them. Stability in the workplace will definitely bring a long-term perspective and inspires further investments in homes and businesses. It will also make a lot economic sense if State and Local governments can make fees payable to the government/private agencies in charge of environmental management/planning (environmental sanitation, health, waste management, land survey, building plans, $\mathrm{C}$ of $\mathrm{O}$ ) affordable. This according to Ibrahim (78) will not only reduce the economic burden of the poor, reduce deviance of the people and combat corruption among the enforcement agents but also lead to desirable increase in revenues accruable the city authorities; thereby making more money available for proper environmental management in Ibadan.

Arising from the above analysis, it has become obvious that development in Ibadan will only become sustainable when there is steady and sustained economic growth; when there is entrenchment of good governance which allows markets to flourish and makes the state/local government institutions and private sector work together as key promoters of development; when the city can raise more funds to fight poverty and manage wastes and sanitation in favor of the poor. Nwadiegwu and Chukwu (79) submitted that the fact that there are many indications that there is high correlation between citizens poverty and environmental management problems, should make governments at all levels pursue vigorously the program of poverty reduction as a way of addressing urban environmental management problems and to ensure its sustainability. Furthermore, environmental managers in Ibadan as a matter of urgency must recognize the fact that in order to achieve environmental sustainability and economic development, they have to make deliberate choice of solid and pragmatic environmental management strategies. Ultimately, some scholars (80) maintained that they must know that 'to manage the life of a city is ultimately to choose a future: to identify priority objectives and the risks that threaten them and then to mobilize resources effectively with which to meet those threats.'

Beyond utilizing socio-economic transformation as tool as urban environmental revolution is the need for attitudinal rejuvenation of the people. While more than half of our informants were honest enough to express their disdain and lack of awareness about the environment; few that showed keen interest in environmental related issues are doing so either superficially or due to professional callings. It was in few instances that one comes across those fighting to protect the environment as a personal calling or conviction. Many of course have reasons for the 
care-free attitude towards the environment (genuine or otherwise) such as poverty, unemployment, failure of government policies to cater for their needs, cultural inhibitions etc. But sincerely most of them are with their present state of mind due to ignorance and lack of environmental consciousness. To this end, this study recommends raising environmental consciousness of the citizens of Ibadan as one of the most critical measure towards regenerating the city. This should be done through entrenchment environmental ethics, environmental education, public enlightenment / mobilization and application of technology.

Environmental ethics is the part of environmental philosophy which considers extending the traditional boundaries of ethics from solely including humans to including the non-human world. Several experts $(81,82)$ posited that it exerts influence on a large range of disciplines including environmental law, environmental sociology, eco-theology, ecological economics, ecology and environmental geography. It addresses many ethical decisions that human beings make with respect to the environment. For examples it attempts to answer some of these questions: should we continue to clear cut forests for the sake of human consumption? Why should we continue to propagate our species, and life itself? Should we continue to make gasoline powered vehicles? What environmental obligations do we need to keep for future generations? Is it right for humans to knowingly cause the extinction of some species for the convenience of humanity? How should we best use and conserve the space environment to secure and expand life? The academic field of environmental ethics grew up in response to the work of scientists such as: Pre- $20^{\text {th }}$ century thinkers include Saint Francis of Assisi and the American transcendentalists Ralph Waldo Emerson and Henry David Thoreau; Aldo Leopold (1887-1948); Rachel Carson (1907-1964) and events such as the first Earth Day in 1970, when environmentalists started urging philosophers to consider the philosophical aspects of environmental problems.A major theme in ecological science and environmental ethics is interdependence.

Just like every other branch of philosophy, environmental ethics is embedded with many theories and approaches in trying to justify the need for environmental codes of conduct. For examples we have: anthropocentricism and eco-centricism. Anthropocentricism sees humans as the most important or critical element in any given situation and concern with human-centered values such as social justice and economic equity. Peter Vardy distinguished between strong and weak anthropocentrism. A strong anthropocentric ethic argues that humans are at the center of reality and it is right for them to be so. Weak anthropocentrism, according Vardy and Grosch (83) however, argues that reality can only be interpreted from a human point of view, thus humans have to be at the centre of reality as they see it. Eco-centricism on the other hand focuses on non-human components of the environment. According to Marshal (84), there are also: social ecology, deep ecology, environmentalism, environmental pragmatism, agrarianism, eco-humanism, eco-feminism, bio-regionalism, religious environmentalism, holism and so on. In all, this study opts for holism because it truly reflects centrality of interdependence in environmental ethics. On one hand, it teaches the world our dependence on the environment for our collective survival. On the other, the ideology shows the people clearly that if we are to survive the current and impending environmental catastrophe, we must take care of the environment with absolute connectivity and interdependence. When views and handling of environment is holistic, it takes of care all (human, non-human, biotic, abiotic, biological, abiological etc.). In this model, the ecosystem is primary and individuals are of less concern. Cities everywhere must take the lead in this race to save the human race by being holistic in the management of the environment.

For effective environmental management in Ibadan, the concerned authorities must incorporate principles of holistic environmental ethics as enunciated above into their systems. The governments at all levels must ensure constant training and retraining of officials in charge of environmental management in the city. The citizens must also be mobilised through sensitization and environmental education. Sensitization will bring about adequate citizen participation and private sector partnership. The public agencies such as Ibadan Waste Management Authority (now Oyo State Waste Management Authority); Ibadan Town Planning Authority (now Ministry of Urban and Physical Development); the eleven Local Government Areas that make up metropolitan Ibadan and Water Corporation cannot alone achieve success in managing the environment without clearly understood working ethics or philosophy which will enhance constructive/positive partnership with the citizens and the private sector. Citizens and public sensitizations espoused by Steg and Vlek (84) will bring about the much needed development of desirable environmental behavior and initiation of neighborhood spirit.

Through Public enlightenment and mobilization and environmental education, the attitude of the people towards improving and maintaining the neighborhood quality will be achieved. The public enlightenment may take several forms and shapes such as: occasional workshops/seminars/trainings for environmental personnel and residents; production of relevant handbills and leaflets; street to street campaigns; regular meetings between authorities and trade unions, market associations, CBOs, NGOs, Landlord/Tenant associations and other concerned groups etc. ate. With this the residents will develop a sense of belonging, some emotional attachment to their neighborhood and thus display a sense of commitment to the cleanliness of the neighborhood and 
Ibadan as a whole. If residents of Ibadan (from neighborhood to neighborhood)are properly organized, sensitized and educated, they can be mobilized to team up and on their own become committed to their neighborhood to the extent that they can on their own take decisions to clean up their neighborhoods and thus improve the processes of environmental management.

Environmental education through the entrenchment of environmental ethics into the school curriculum from primary to tertiary levels in Ibadan is another potent measure to institutionalize the proposed solutions. This must go beyond aspects of teaching of personal hygiene which has been incorporated into subjects like civic education, social studies, health science etc. Environmental ethics should be floated as separate subjects (at basic level at both primary and secondary) at advanced level at tertiary level which may start as part of General Studies in all our tertiary institutions in Oyo State (Ibadan) at the first instance. In order to achieve maximum results, Ojomo (85) opined that traditional/ indigenous environmental ethics must be taught at both formal and informal levels. At formal level, indigenous and foreign environmental ethics may be incorporated into the Yoruba Language and Literature curricular from primary to tertiary level. Special trainings in environmental ethics and management must be organized for the teachers and lectures at regular interval. Both Oyo State and the affected Local Governments may also seek financial assistance and partnership from corporate bodies, academic and research institutes, Federal Government of Nigeria and international development partners such as UNDP, UNEP, UN-Habitat, City Alliance etc.

Application of technology in the opinion of some scholars (86) will also go a long way in improving environmental standard in Ibadan. For instance, as contended by Relis and Dominiski (87) there is the urgent need for authorities in Ibadan to evolve a new technology that will pave way for integrated waste management (IWM) which is best defined as a set of management alternatives including reuse, source reduction, .recycling, composting, landfill and incineration. With this technology, waste will no longer exist because it will not be produced and if produced, would be a resource to be used again. At best, this will lead to what Nwadeigwu and Chukwu (88) referred to as 'waste to wealth' concept or industrial ecology in which Ibadan would be functioning more like an ecological system where waste from one part of the system would be a resource for another part. These measures will also encourage maximum protection against possible health risks that commonly emanate from careless refuse disposal practices and landfill sites. Geographic Information Management Systemsis equally crucial to Ibadan city planning and management. Unfortunately, previous and existing developmental initiatives in Ibadan are often based on fragmented information; hence, the constant failures. Therefore, it has become most important for environmental managers in Ibadan to take advantage of Geographic Information technology to gather, analyse and manage information in order to identify, prioritise and handle problems that emerge as a result of developmental efforts.

This study concludes that while it impossible to rebuild Ibadan from the scratch; transformation is a possibility. Therefore, regenerating and making development in Ibadan sustainable is herculean but not impossible. If Ibadan will become sustainable, the city must rely more on critical human infrastructure which will be the bedrock for physical infrastructure. With this, Ibadan will become all-inclusive where all residents irrespective of their socio-economic status will be captured by developmental programs and environmental policies of government at all levels. All agencies and personnel in charge of the environment must be empowered for proper public enlightenment and enforcement of environmental laws and regulations. If these recommendations are followed sincerely, one can hope that in no distant future, Ibadan will successfully transit from what Solarin (89) called 'a civilization without toilets' to a hub of ecological transformation.

\section{REFERENCES}

[1] Darshini Mahadevia, "Sustainable Urban Development in India: An Inclusive Perspective", in David Westerndorff ed., From Unsustainable to Inclusive Cities, (Geneva: An UNRISD Publication in Collaboration with Swiss Agency for Development Cooperation, October 2002, 2-19).

[2] Ibid. 4.

[3] Ibid.

[4] Walter Rodney, How Europe Underdeveloped Africa....30

[5] Interview with Professor Akin Mabogunje - The globally renown doyen of African/Nigerian Urban geography at his Bodija, Ibadan residence

[6] Ibid.

[7] the UN Conference on Human Settlements in Vancouver June 1976

[8] R.A. Boroffice, "Environment and Development", in S. Otokiti and S.G. Odewunmi eds., Issues in Management and Development, (Ibadan, Rex Charles Publication, 2001). 587 -596 .

[9] Aidan Campbell, Western Primitivism: African Ethnicity - A Study in Cultural Relation, (London, Cassell Press, 1997). 86

[10] Laurent Fourchard, Urban Slums Reports: The Case of Ibadan, Nigeria.

[11] Herbert Werlin, Governing an African City, A Study of Nairobi, (New York: Routledge, 1974). 12. 
[12] A. G. Onibokunet et al., eds., Urban Renewal in Nigeria, (NISER, 1987). 10.

[13] I. L. Lindell, Walking The Tight Rope: Informal Livelihood and Social Networks in a West African City, (Stockholm, Stockholm University Press, 2003)

[14] Justin Labinjoh, "Ibadan and the Phenomenon of Urbanism", in G. O. Ogunremi ed., A Historical and Socio-Cultural Study of an African City, (Ibadan: Oluyole Club, 1999), 234.

[15] Onibokun: 1987, Abumere: 1987, NISER: 1997, Labinjoh, 1999, and Fourchard: 2003.

[16] P. C. Lloyd, Africa in Social Change, (Baltimore: Penguin, 1967). 3.

[17] See the prologue in Dapo Adelugba ed., Ibadan MESIOGO: A Celebration of a City, its History and People, (Ibadan: Bookcraft Ltd, 2002). 2.

[18] See The Executive Summary of a 2013 Special Report by The United Nations' Agency for Human Habitat: The State of European cities in transition: taking stock after 20 years of reform" available online at www.unhabitat.org. Accessed on 20 August, 2015.

[19] Herman E. Daly and John B. Cobb Jr, For the Common Good: Redirecting the Economy toward Community, the Environment, and a Sustainable Future, (Boston: Beacon Press, 1989).

[20] Commonwealth Government, Ecologically Sustainable Development: A Commonwealth Discussion Paper, (Canberra: AGPS, 1990).

[21] Schaltegger Stefan et al., An Introduction to Corporate Environmental Management: Striving for Sustainability, (Sheffield: Greenleaf, 2003). 4.

[22] David Foster, The Role of the City in Environmental Management Regional Environmental

[23] Soeren Jeppesen, Joergen Eskemose Andersen and Peter Vangsbo Madsen, "Urban Environmental Management in Developing Countries - Land Use, Environmental Health and Pollution Management, Research Network on Environment and Development", available online at www.ReNED.dk. Accessed on $21^{\text {st }}$ August, 2015.

[24] Ibid.

[25] A. M. Kjaer, "Central Government Intervention as Obstacle to Local Participatory Governance: The Case of Uganda." Paper prepared for the ILO Conference on Governance, 2005. 9-10.

[26] UN-HABITAT (United Nations Human Settlements Programme), "I'm a City Changer", available online at www.worldurbancampaign.org andwww.imacitychanger.org. Accessed on $21^{\text {st }}$ August, 2015.

[27] Ibid.

[28] Ibid.

[29] World Bank, Sustainable Development in a Dynamic World: Transforming Institutions, Growth and Quality of Life, (World Bank and Oxford University Press, 2003).108-110.
[30] UNDP Governance and Sustainable Development, (New York, 1997). 2-3.

[31] UN-HABITAT (United Nations Human Settlements Programme) and Transparency International, Tools to Support Transparency in Local Governance: Urban Governance Tool Kit Series, (Nairobi: UN-HABITAT, Secretariat, 2004).1-4.

[32] For instances, Mabogunje: 1968, Onibokun: 1987, Abumere: 1987, NISER: 1997, Labinjoh, 1999, Fourchard: 2003 have come to same conclusion about the enduring negative implication of absence of any credible Master Plan forurban planning and development of Ibadan. Many of experts interviewed such as: Prof. Mabogunje, Dr. Idowu Johnson, Dr. Dickson Ajayi, Dr. Femi Olaniyan, Dr. Murtala Monsor, Dr. Godwin Ikwuyatum, Mr. S.B. Taiwo, Mr. AdemolaDaud Michael Adeleke also came the same conclusion

[33] Interview with Mr. S.B. Taiwo (Deputy Director, Development Planning, Oyo Ministry of Urban and Physical Planning)

[34] Interview with Dr. Femi Afolayan

[35] Ibid.

[36] Interview with Mr. S.B. Taiwo.....

[37] Interviews with: Mr. Dauda Ogundeji, a trader, Iyana Agbala Itura, Old Ife Road Ibadan; Mr. Olagunju Oyebajo, Furniture maker, Adegbayi area, Ibadan and Mrs. Aina Iyanda, Alakiaarea, Ibadan on Miss Bankole Olaogun, a Secretary in a Law Firm, at Alakia area, Ibadan; and Mr. Lanre Atanda, a businessman Bola Ige international market ,Ibadan on 14/01/14

[38] Interview with Mr. S.B. Taiwo.....

[39] Mr. O. Oyewole, HOD or Director, Environmental Health Dept. En Mrs. B.O. Areo, Principal Environmental Health Officer and Mr. K.K. Popoola (Chief Environmental Officer, Oyo Ministry of Environment and Habitat 6/1/15.

[40] Interview with Mr. Ademola Daud (Senior Technical Officer, Oluyole Local Government office of Oyo State Ministry of Urban and Physical Planning on 20/01/16

[41] Ibid.

[42] Interviews with Mr. S. B. Taiwo,, MrDaud, Mr. Michael Adeleke (Deputy Director Town Planning Office, Ibadan North LGA); Mr. Akinpelu Jegede (OnaAra Local Governt Area); My Yomi (Egbeda Local Government Area); Mr. Onaolapo Abideen (Ibadan North-east Local Government); MrAkinola (Ibadan South-west Local Government Area);

[43] "Constraints on Sustainable Development in Sub-Saharan Africa”, http://unu.edu, accessed on $23^{\text {rd }}$ August, 2014

[44] B. von Droste and P. Dogse, "Sustainable Development: The Role of Investment", in R. Goodland, H. Daly, S. el Seraty, and B. von Droste eds., Environmentally Sustainable Economic Development: Building on Brundtland, (Paris: UNESCO, 1991). 71-82.

[45] Ibid.

[46] Interview with Dr. Dickson Ajayi at the Department of Geography, University of Ibadan on 20/1/16 
[47] Interview with Godwin Ikwuyatum at the Department of Geography, University of Ibadan on 20/1/16

[48] Interview with Dr. Femi Afolayan.

[49] Onibokun, Adepoju "Forces Shaping the Physical Environment of Cities in the Developing Countries: The Ibadan Case", Land Economics, Vol. 49, No. 4, (Nov., 1973), 424-431.

[50] Fourchard, Ibadan....12

[51] This took the researcher to all the eleven Local Government Areas that form the study area for this research. I must state here that, series of visits to the affected areas and interviews conducted strongly confirmed what the researcher as a resident of the city had been encountering over three decades. The filthy nature of post-colonial Ibadan is staggering and simply unbelievable especially in core areas like Beere, Oje, Agugu, Idi arere. Oranmiyan, Oke-adu, Itutaba, Gege, Okefoko, Beyerunka, Isale-jebu, Orita-merin, Inalende, Omitowoju , Abebi, Bode, Itutaba and so on. In these areas, there is near- zero presence of sanity in terms of planning, waste management and sanitation. Congestion everywhere; refuse usually litter the environment and due to absent of personal or public toilets, people normally defecate at any available space (sometimes at night and many times in broad day light) without any shame. So the situation in those areas is better imagined than experienced! Unfortunately, the supposed new areas such as Mokola, Bodija, Oke -Ado, Challenge, Ring - Road, Eleyele, Sango, and Satelite towns and fringes (Ajibode, OjooApete, Ido etc) are also not immuned against these environmental maladies. Both the people and the government refused to learn from the past, hence the crisis is escalating in those new areas and if care is not taken, the situation could be worse in some instances.

[52] Interviews with: Miss. Oluwaseyi Adebayo, a trade apprentice, at Beere area, Ibadan; Mr. Odunayo Adigun, a bricklayer, at Inalendearea, Ibadan; Mr. Kazeem Ijadunola, a photographer at born foto (Gege area) Ibadan; Mrs. Mistura Ibikule, a trader at Oja Oba area, Ibadan; Mr. Olusola Anjorin, a motor spare part dealer, Adebisi Compound, Oje area, Ibadan. From 6/02/14

[53] Interview with Dr. Godwin Ikwuyatum.

[54] Outcome of personal visits and direct observation which was carried between January and March, 2015

[55] Ibid.

[56] Ibid. Interviews with Mr. Olusegun Johnson, student 30 , University of Ibadan; Mrs. Monsura Aremu, trader, Bodija market, Ibadan; Mr. Alimi Okunade, a surveyor, Poly road, Ibadan; Mr. Victor Bishop, a technician/interior decorator, Oremeji, Mokola, Ibadan; Mr. Dare Olukayode, a teacher, at his residence New Bodija area, Ibadan on 16/01/14

[57] Interviews with: Mr. Isaiah Orelusi, a business man, Lebanon Street, Dugbe, Ibadan and Mr. Odunayo Kilani, Accountant, Jericho, Ibadan; Mrs. Adedeji Suliat, a teacher, Sango, area Ibadan; Mr. Bankole A. a police officer 35, Police Headquarters, Eleyele, Ibadan; Mr. Taye Adegun, a welder, Abebi area, Ibadan on 17/01/14. Interviews with Mr. Ndigi Emi, a teacher at Orogun area, Ibadan ; Mr. Ladipo Olabode ,a transporter at Ojoo area, Ibadan; Mr. Oduniyi Akeem, a businessman at Ojoo area, Ibadan; Mr. Jamiu Esuola, a farmer at Ijaye via Moniya, Ibadan; and Mr. Damilare Olusesan, Akinyele village, Ibadan from 03/02/14 to $04 / 02 / 14$

[58] World Bank, www.worldbank.org/1992report, accessed on $20^{\text {th }}$ August, 2015.

[59] Interview with Dr. Ikwuyatum.

[60] A. T. Busari and M.O. Olaleye, "Urban Flood and Remediating Strategies in Nigeria: The Ibadan Experience", The International Journal of Environmental Issues, Vol. 6, No. 1 and 2, (2004). 7; and Ebenezer Adurokiya, "The Search for Environmental Sanity in Oyo", Nigerian Tribune, 24 September, 2011. 36.

[61] David Taiwo (SIP Project Manager), Ibadan: Mobilising Resources through a Technical Coordinating Committee, http://ww2.unhabitat.org/programmes/uef/cities/summary/i badan.html, accessed, $25^{\text {th }}$ August, 2015.

[62] Foreword by Anna K. Tibaijuka Under-Secretary-General and Executive Director United Nations Human Settlements Programme (UN-HABITAT) "São Paulo: A Tale of Two Cities: Bridging the Urban Divide" in UN-HABITAT Cities \& Citizens Series ht (C) United Nations Human Settlements Programme (UN-HABITAT), 2010, ww.unhabitat.org.

[63] Sam Omatseye "Redeeming Ibadan" http://thenationonlineng.net/new/sam-omatseye/redeemingibadan/., accessed on $15^{\text {th }}$ August, 2015.

[64] Ibid.

[65] UN-HABITAT (United Nations Human Settlements Programme), "I'm a City Changer", available online at www.worldurbancampaign.org and www.imacitychanger.org, accessed on $21^{\text {st }}$ August, 2015.

[66] Darshini Mahadevia, "Sustainable Urban Development in India: An Inclusive Perspective", in David Westerndorff ed., From Unstainable to Inclusive Cities, (Geneva: An UNRISD Publication in Collaboration with Swiss Agency for Development Cooperation, October 2002). 3.

[67] G. E. Machliset et al., "The Human Ecosystem Part I: The Human Ecosystem as an Organizing Concept in Ecosystem Management", Society \& Natural Resources, 10, (1997). 347-367; C.H. Nilonet et al. "Editorial: Understanding Urban Ecosystems: A New Frontier for Science and Education", Urban Ecosystems, 3, (1999). 3-4.

[68] United Nations Environmental Programme (UNEP) Global Environment Outlook 3: Past, Present and the Future Perspectives, [On-line], 2002. Available at: http://www.unep.org/geo/geo3/, accessed on $15^{\text {th }}$ July, 2014.

[69] The Sustainable Cities Programme: Approach and Implementation, written and published by the United Nations Centre for Human Settlements (Habitat), Nairobi, Kenya, 2nd edition 1998.

[70] The SCP Source Book Series, Volume 5 Institutionalising the Environmental Planning and Management Process Ibadan, Nigeria.

[71] Ibid.

[72] Interviews Dr. Femi Afolayan and Mr. S. B. Taiwo.

[73] Available online at www.unhabitat.org/issue-papers-and-policy-units, accessed 
on $23^{\text {rd }}$ August, 2015.

[74] Sally Roever "The People's Economy and the Future of Cities", available online at www.wiego.org/.../ the people's economy and the future of cities....

[75] This view according to the United Cities and Local Governments' Global Charter-Agenda for Human Rights in the City is available online at www.cities-localgovernments.org.

[76] Roever Sally....

[77] Interview with Mr Kehinde Ibrahim.

[78] B.O. Uwadiegwu and K. E. Chukwu, "Strategies for Effective Urban Solid Waste Management in Nigeria", European Scientific Journal, Vol. No. 8, (March 2013 Edition). 296-307.

[79] Soeren Jeppesen, Joergen Eskemose Andersen and Peter Vangsbo Madsen "Urban Environmental Management in Developing Countries - Land Use, Environmental Health and Pollution Management - A Review", (ReNED Research Network on Environment and Development, www.ReNED.dk) and A. M. Kjaer, "Central Government Intervention as Obstacle to Local Participatory Governance: The Case of Uganda." Paper prepared for the ILO Conference on Governance, 2005. 9-10.

[80] For details on Environmental ethics see: Peter Vardy and Paul Grosch, The Puzzle of Ethics, (New York: Harper Collins, 1999); Alan Marshall, "Ethics and the Extraterrestrial Environment", Journal of Applied Philosophy, Vol. 10, No. 2, (1993). 1468-5930; Peter Singer, Practical Ethics, (Cambridge: Cambridge University Press, 2011); Peter Scott, "Ecology: Religious or Secular?" Heythrop Journal, Vol. 38, No. 1, (January 1997); William Cronon, ed., Uncommon Ground: Rethinking the Human Place in Nature, (New York: W.W. Norton \& Co., 1995). 69-90; Peter Singer, "Environmental Values", in Ian Marsh ed., The Oxford Book of Travel Stories, (Melbourne, Australia: Longman Chesire, 1991). 12-16; Lynn White,
"The Historical Roots of our Ecologic Crisis", Science, Vol. 155, No. 3767, (1967). 1203-1207; Garrett Hardin, "The Tragedy of the Commons", Science, Vol. 162, No. 3859, (1968). 1243-8. Aldo Leopold, "The Land Ethic". A Sand County Almanac. 1949.

[81] Ibid.

[82] Peter Vardy and Paul Grosch, The Puzzle of Ethics, (New York: Harper Collins, 1999). 5-7

[83] Alan Marshall, "Ethics and the Extraterrestrial Environment", Journal of Applied Philosophy, Vol. 10, No. 2, (1993). 1468-5930.

[84] Linda Steg and Charles Vlek, "Encouraging Pro-Environmental Behaviour: An Integrative Review and Research Agenda", Journal of Environmental Psychology, Vol. xxx, (2008). 1-9.

[85] P. A. Ojomo, "Environmental ethics: An African Understanding", Journal of Environmental Science and Technology, Vol. 5, No. 8. (August, 2011). 572-578. Available online at http://www.academicjournals.org/AJEST, 1-7

[86] B. O. Uwadiegwu and K. E. Chukwu, "Strategies for Effective Urban Solid Waste Management in Nigeria", European Scientific Journal, Vol. 9, No. 8, (March 2013 Edition); G.E.D. Omuta, "Urban Solid Waste Generation and Management; Towards an Environmental Sanitation Policy", in P.O Sada and F.O. Odemerho eds., Environmental Issues and Management in Nigerian Development, (Ibadan: Evans Brothers Ltd. (Pub), 1988).

[87] P. Relis and A. Dominiski, "Beyond the Crisis, Integrated Waste Management", (Santa, Barbara: Community Environmental Council Publication, 1987).

[88] B. O. Uwadiegwu and K. E. Chukwu, "Strategies for Effective Urban Solid Waste Management in Nigeria".

[89] Tai Solarin, "Civilization without Toilets", Nigerian Tribune, August 16, 1972. 2. 